\title{
Structure and precursors of the 1992/93 drought in KwaZulu-Natal, South Africa from NCEP reanalysis data
}

\author{
Lawrence T Dube* and Mark R Jury \\ Department of Geography \& Environmental Studies, University of Zululand, KwaDlangezwa 3886, South Africa
}

\begin{abstract}
The historical context and potential causes and structure of the 1992/93 drought in KwaZulu-Natal are analysed using NCEP reanalysis data. The analysis indicates that increased westerly winds with surface marine lows and continental highs prevailed over Southern Africa. Anomalous divergence and subsidence occur over the eastern subcontinent, coupled with reduced tropical moist inflows. Mid-latitude confluence, anticyclonic vorticity and upper level convergence suppressed convection over KwaZulu/Natal. The precipitable water field reflects a SE-NW orientated stationary wave-train pattern over Southern Africa with KwaZulu-Natal anti-phase with the Zambezi valley. A meridional overturning cell is seen as a driving mechanism behind the 1992/93 drought over South Africa. The velocity potential shows a dipole between the Zambezi and the SW Indian Ocean, and it appears that the kinematic structure was more important than the thermodynamic. Impacts include a reduction in crop yield and streamflows, and a slowing of economic activity.
\end{abstract}

Keywords:

\section{Introduction}

The majority of the population in Southern Africa rely on agriculture at a subsistence level for food and are particularly susceptible to changes in rainfall and climate. This problem is exacerbated by the high degree of inter-annual and intra-seasonal rainfall variability over the Southern African subcontinent (Preston-Whyte and Tyson, 1988; Crimp, 1997). Another factor compounding the drought problem is the growing population of Southern Africa which is placing increasing pressure on already limited water resources. Improving the understanding and prediction of the weather systems affecting Southern Africa will be of assistance to engineers, hydrologists and agriculturalists in effective water management and in ensuring food security for the population.

Widespread and sustained droughts that have periodically afflicted Southern Africa over the past three decades are those in 1964, 1968, 1970, 1982, 1983 and 1984, often in association with the El Niño (Preston-Whyte and Tyson, 1988). From 1987 to 1996 KwaZulu-Natal experienced a gradual decline and rise of rainfall (Fig. 1a), with the minimum reached in 1992/93. Various drought simulation studies with predicted sea surface temperatures (SSTs) as inputs, have been undertaken in South Africa and elsewhere (Walker, 1989; Hunt, 1991; Mason., 1992; Montecinos et al., 1997; Mullan et al, 1997; Rautenbach, 1997; Ronchail, 1997; Pathack et al., 1993; Landman et al, 1997; Rocha and Simmonds, 1997 a, b; Thiao and Barnston, 1997). Statistical techniques have also been employed (Landman, 1994; Hastenrath, 1995; Mason et al., 1996; Landman et al., 1997; Jury, 1998) to demonstrate structure and causality. QBO signals and ENSO teleconnections to climate anomalies over Southern Africa have been studied (Lindesay, 1988; Jury, 1992; Jury and Levey, 1993; Jury et al., 1993; Jury et

\footnotetext{
* To whom all correspondence should be addressed.

政+27 35902 6324; fax: +27 359026338 e-mail: 1tdube@pan.uzulu.ac.za Received 23 March 2001; accepted in revised form 11 December 2002.
}

al., 1994; Pathack et al., 1993; Jury, 1997). All these efforts highlight a wide scope to be covered in search of improved drought forecasting skill and a better understanding of drought-inducing meteorological processes. Acquiring accurate drought forecast skills has been such a priority that National Meteorological Services and tertiary institutions across Africa are undertaking research on this application whose value is increasingly appreciated by agriculturalists, hydrologists and politicians for decision-making (South African Weather Bureau, 1992; Jury, 1996). It is against this background that a study on precursors of the 1992/93 drought over KwaZulu-Natal was accomplished.

\section{Background and methods}

KwaZulu-Natal is located along the east coast of South Africa. Climatologically it is classified as a summer rainfall region. The altitude ranges from sea level to over $3000 \mathrm{~m}$, resulting in a considerable range in temperature. Topography varies from the flat coastal plains of Maputaland to the rugged, broken terrain of the Valley of a Thousand Hills and the Drakensberg Mountains. The rainfall also varies considerably, from $500 \mathrm{~mm}$ to over 2000 $\mathrm{mm} / \mathrm{a}$. River systems of the province run west to east, cutting through geological layers and resulting in deeply incised valleys (Camp et al., 1995; Camp, 1997). Extremes of maximum temperatures and evaporative losses are low due to the moderating effect of the Agulhas Current.

With this variation in topography, geology and climate, KwaZulu-Natal possesses enormous diversity of natural resources. In recent years, however, increased water demand from the urban, industrial, and agricultural centres has placed an untenable burden on the environment. Following the 1992/93 drought, urban water restrictions were in force, many farmers went bankrupt, and there were major economic repercussions (Financial Mail, 1993a, b, c; The South African Sugar Association, 1993a, b, c; Landbouweekblad, 1993; Farmer's Weekly, 1993). 
KZ NATAL RAINFALL

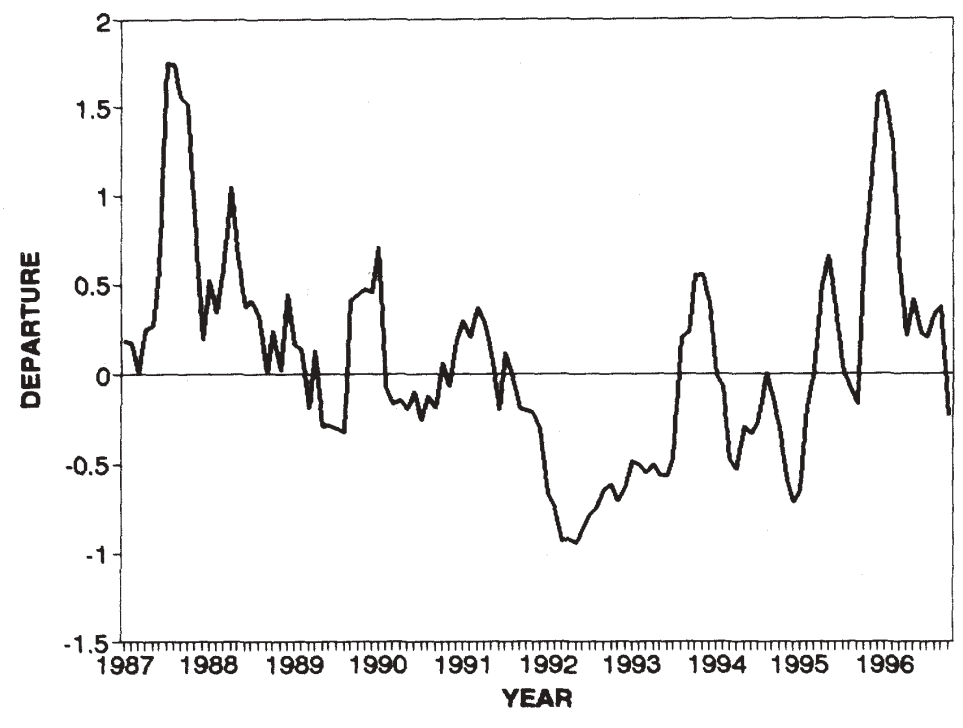

RAINFALL ANOMALY $\mathrm{mm} /$ day

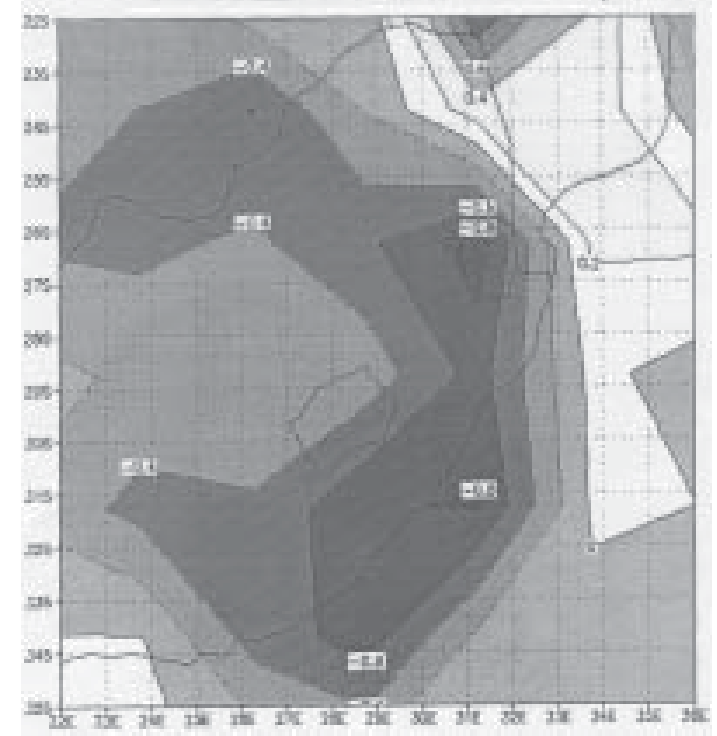

Figure 1

(a) Rainfall time series (standardised anomalies) for KwaZulu/-atal over the period 1987-1997, to place the 92-93 drought in perspective; (b) rainfall anomaly map (mm/day) for the period Oct.1992 to Feb. 1993 based on station and satellite data

(a)

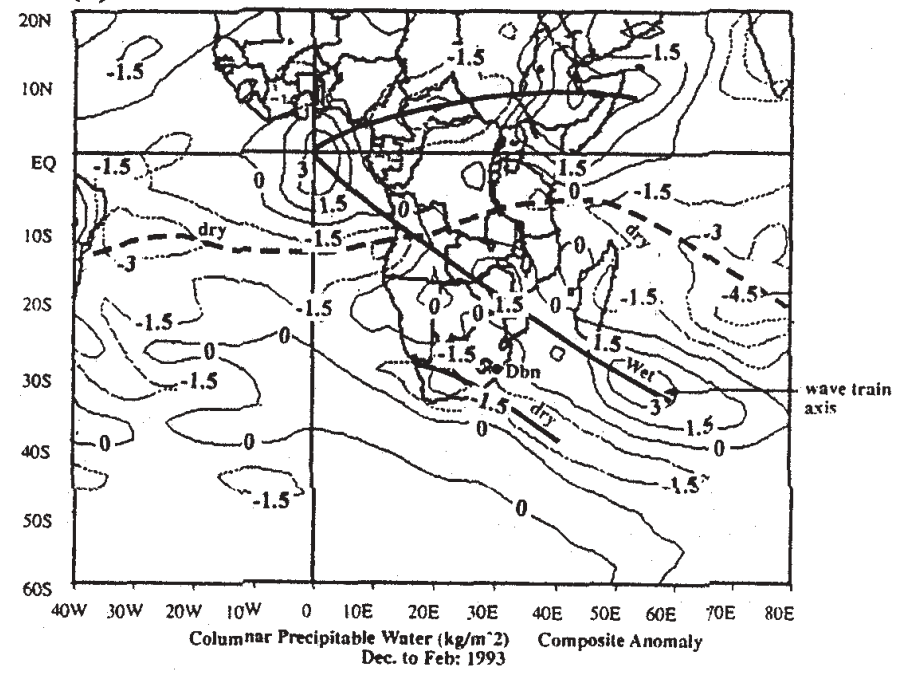

(b)

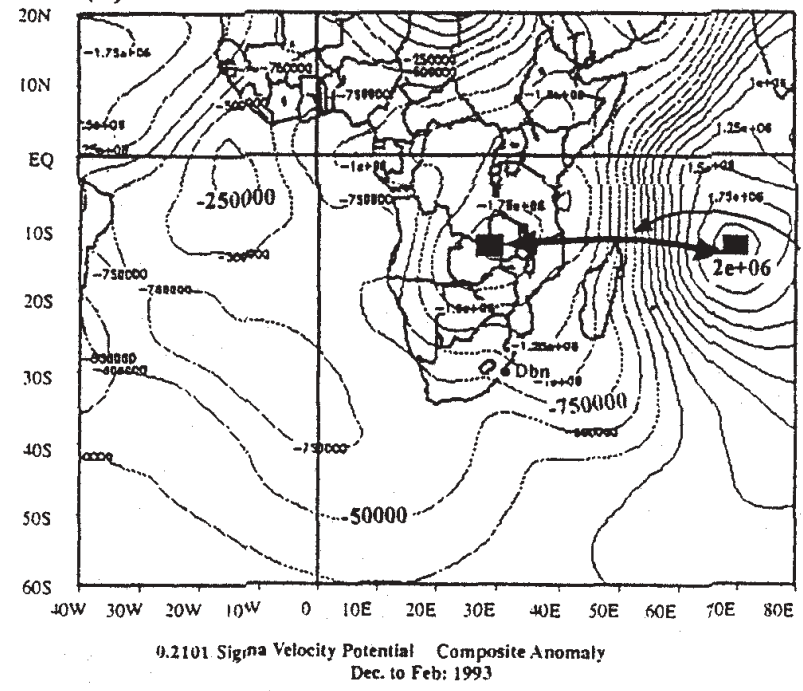

This paper describes the origin and structure of the 1992/ 93 drought from NCEP reanalysis data at a resolution of $2.5^{\circ}$ x $2.5^{\circ}$. To achieve this objective, meteorological modelgenerated fields for precipitable water; vertical motion; zonal wind and velocity potential are utilised. Means and anomalies of these variables are computed to establish patterns of circulation and convection over the region. Temperature, relative humidity, wind speed, and dew-point temperature station data for Estcourt, Cedara (Pietermaritzburg) and Durban obtained from the South African Weather Bureau are used to quantify evaporative losses and associated boundary layer conditions over KwaZulu-Natal.

\section{Results}

\section{Climatic conditions}

In this section the anomaly fields are interpreted.

The October 1992 to February 1993 rainfall anomaly is shown in Fig. 1b. A large area of below-normal rainfall is found over South Africa. The dry axis extends along the east coast from East London to Swaziland. The geopotential height anomaly field (not shown) reveals a mid-latitude trough over the ocean to the south of Africa, a pattern known to induce dry westerly flow over the east coast.

Model-interpolated precipitable water is $\sim 2 \mathrm{~kg} \cdot \mathrm{m}^{-2}$ below normal and displays a wave train pattern orientated NWSE (Fig 2a). Consideration of its history indicates this to be a stationary feature with little propagation. Above-normal precipitable water is located over the Zambezi valley extending toward Madagascar. Another below-normal axis is found in the zone of the ITCZ around 10S. The wavelength of the

Figure 2 (left)

DJF 1993 anomalies of (a) precipitable water $(\mathrm{mm})$; (b) upper level velocity potential $\left(\mathrm{kg} \mathrm{m}^{2} / \mathrm{s}\right)$, based on NCEP reanalysis data 

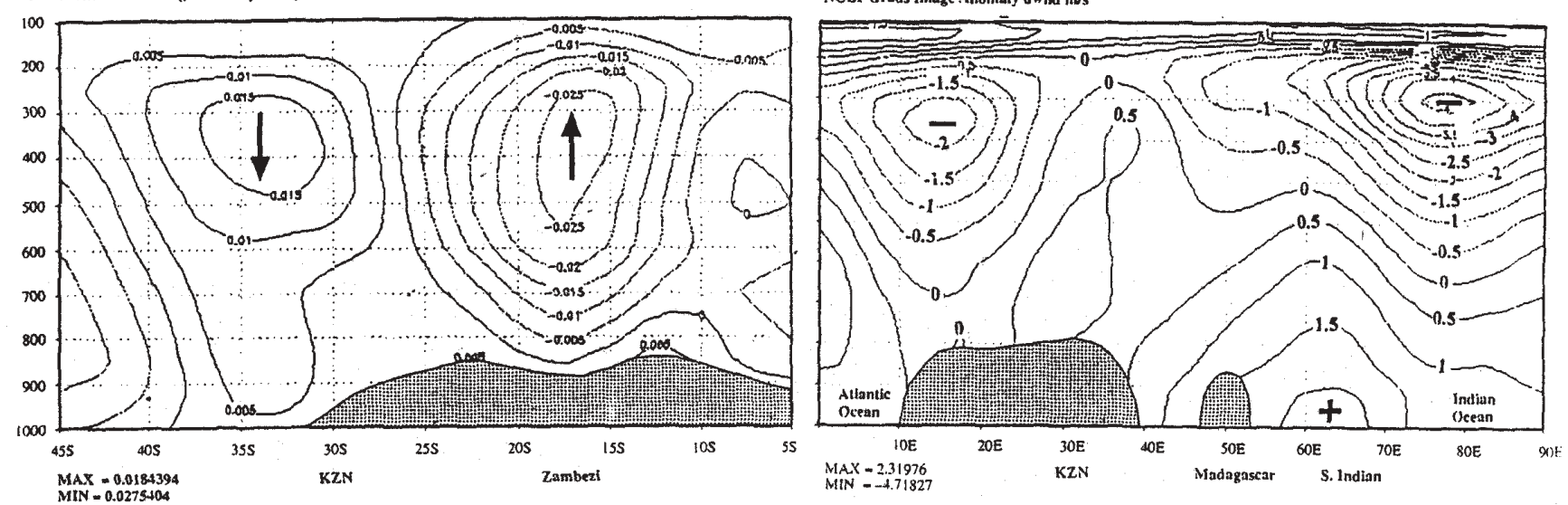

Figure 3

DJF 1993 anomalies in vertical slice from 1000 to $100 \mathrm{hPa}$ of (a) vertical motion (Pa/s) on $30 \mathrm{E}$; (b) zonal wind (m/s) on $30 \mathrm{~S}$, based on NCEP reanalysis data

(a)

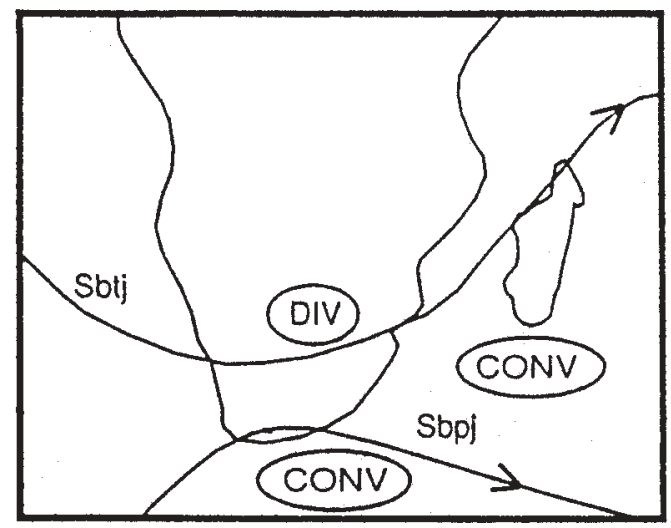

(b)

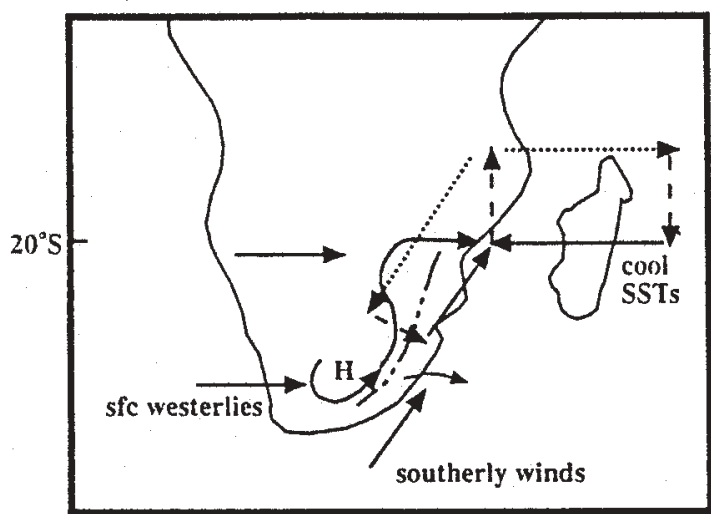

Figure 4

Schematic illustration of (a) position of the subtropical and subpolar jet streams, and (b) local circulations associated with the drought. Solid lines are surface winds, dotted are upper winds and dashed are vertical motions

system is $4000 \mathrm{~km}$, a rather short-length scale for a standing wave.

The sea-surface temperature patterns over the adjacent Indian and Atlantic Oceans were weak, with generally below normal SSTs north of 20S, and above normal to the south. The Atlantic and Indian Oceans were in-phase, unlike that typically generated by an El Niño. A warmer south Indian Ocean was thought to be responsible for 'pulling' water vapour away from KwaZulu-Natal (Dube and Jury, 2002). The equatorial Pacific remained neutral during this event, following the El Niño of the previous year. Hence thermodynamic coupling was weak, and the circulation patterns became more important.

The lower level velocity potential anomaly was divergent over the west Indian Ocean and convergent over the Zambezi valley (Fig. 2b). Hence the zonal overturning circulation directed moisture fluxes toward Africa, but were confined to the lower latitudes.

In N-S vertical section, an alternating pattern of sinking and rising motion is found along $30^{\circ} \mathrm{E}$. Hence subsidence was strong over KwaZulu-Natal, whilst rising motion is located over the Zambezi (Fig. 3a). Westerlies were increased over KwaZulu-Natal and the Indian Ocean east of Madagascar (Fig. 3b). Moisture was diverted, resulting in localised drought over KwaZulu-Natal. There- fore the meridional overturning and zonal circulations inhibited convective events in South Africa.

\section{Discussion}

\section{Jet stream influence}

A climatic feature of the 1992/93 drought is negative geopotential anomalies south of Africa, increased westerly flow and a Rossby wave train. There was a southward shift of the subtropical jet stream and a northward shift of the subpolar jet (Fig. 4a) in agreement with Barclay's (1992) dry troughs analysis. A compressed thermal gradient coincided with an upper-level anticyclone centred around $25^{\circ} \mathrm{S}$. Positive geopotential height anomalies over South Africa and negative anomalies to the south suggest a poleward shift of kinetic energy in agreement with Mulenga (1998).

The shift in position of the subtropical jet stream contributed to the decline of summer rainfall over south-east Africa. It brings the descending limb of the meridional overturning circulation over South Africa. Figure $4 \mathrm{~b}$ is a conceptual model indicating the influence of winds and Indian SSTs on rainfall over Southern 


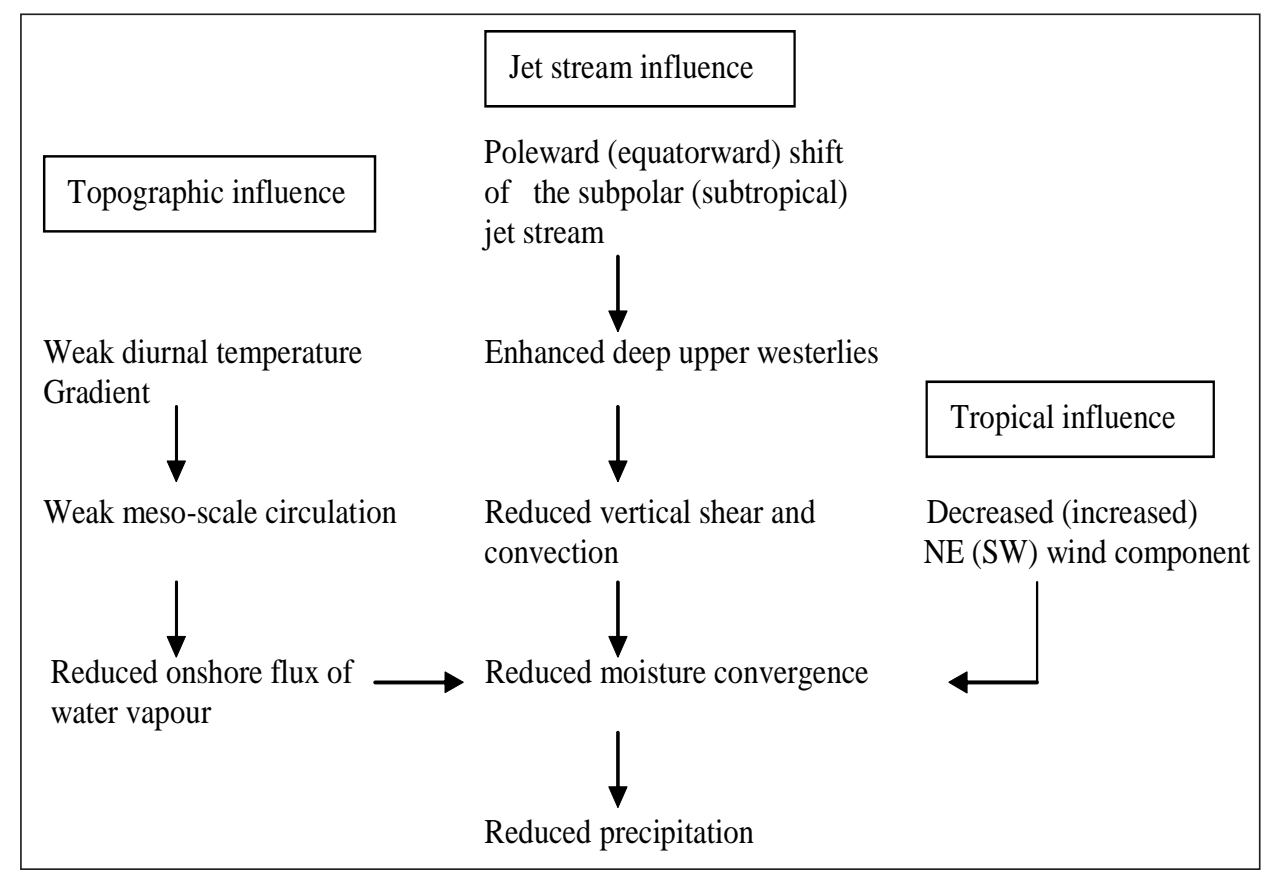

Figure 5

Conceptual flow chart of

the influences of jet streams, local circulations and tropical effects on the drought over KwaZuluNatal

Africa during the 1992/93 drought season. Cooler SSTs over the east coupled with a strong velocity potential anomaly gradient (Fig. 2b) generate easterly anomalies over northern Madagascar and ascend in the Zambezi Valley and descend at $30^{\circ} \mathrm{S}$ (Fig. 3a).

The Rossby wave train during the 1992/93 summer drought had a zonal wavelength of $\sim 4 \times 10^{3} \mathrm{~km}\left(\mathrm{~L}_{x}\right)$ and latitudinal width of $\sim 2 \times 10^{3} \mathrm{~km}\left(\mathrm{~L}_{y}\right)$. The calculated wave speed relative to the zonal flow from the equation for a Rossby wave $c_{x}-u=-\left[\beta /\left(k^{2}+m^{2}\right)\right]$ (Haltiner and Williams, 1980) is $1 \mathrm{~m} \cdot \mathrm{s}^{-1}$. This suggests that the synoptic scale Rossby wave train moved very slowly from spring to summer 1992/93 over south-east Africa. The waves appear to be unrelated to the ocean heat anomalies.

\section{Tropical influences}

Over most parts of the summer rainfall region of South Africa, enhanced rainfall is associated with airflow from a northerly direction. These rain-bearing winds are consistent with deep tropical low-pressure disturbances, either in the form of easterly waves or lows forming over Botswana and adjacent regions (D'Abreton and Tyson, 1996; Preston-Whyte and Tyson, 1988). The absence of these winds during the 1992/93 dry summer limited moisture influx into KwaZulu-Natal. The advection of dry air from the southwest sweeping through the Karoo desert of western South Africa into KwaZulu-Natal contributed to drought conditions (Dube and Jury, 2002). The southerly winds (Fig. 4b) entered a zone of lower Coriolis, resulting in a sinking motion over KwaZuluNatal. The hemispheric wave train in precipitable water was part of an 'atmospheric conspiracy' to inflict dry conditions over KwaZuluNatal (Fig. 5). The major water vapour source region for South Africa is the Indian Ocean around Madagascar. The advection of dry subsiding air from the South Atlantic Ocean into South Africa is a feature of no-rain days (D'Abreton and Tyson, 1996). Thus, the moisture-laden air from the tropical region was confined to the north.

\section{Local topographic circulations}

The dominance of anticyclonic conditions and the entrainment of seabreezes into the gradient westerly wind produced increased stability and solar insolation. Evaporative losses over KwaZuluNatal were calculated (Table 1) from the Meyer Equation:

$$
\mathrm{E}=\mathrm{c}\left(\mathrm{e}_{\mathrm{s}}-\mathrm{e}_{\mathrm{a}}\right)(1+\mathrm{V} / 10)
$$

where:

$\mathrm{c}$ is a coefficient which is a function of wind and atmospheric pressure (-0.36);

$\mathrm{e}_{\mathrm{s}}$ and $\mathrm{e}_{\mathrm{a}}$ are saturation vapour pressure and vapour pressure respectively; and

V is wind speed (Schulz, 1976).

Evaporation is higher over Durban, indicating that the drought effect was more pronounced over coastal areas of KwaZulu-Natal. High surface temperatures over Southern Africa led to excessive evaporative losses which contributed to a decline in agricultural production, vegetation cover, and stream flow (Dube and Jury, 2000).

Average daily specific humidities for the 1992/93 DJF season estimated from $q=0.622 \mathrm{e} /(p-0.378 \mathrm{e})$ (McIlveen, 1986) are $1 \times 10^{-2}$, $1.6 \times 10^{-2}$ and $1.8 \times 10^{-2} \mathrm{~g} \cdot \mathrm{kg}^{-1}$ over Escourt, Cedara and Durban, respectively. Very little precipitation was possible under an atmosphere that was so dry.

\section{Budget calculations}

Comparisons of the magnitudes of the anomalies for the analysed variables and their respective composite means were made. Variables with the greatest departures from their composite means $(>1)$ are velocity potential, vertical motion and stream function. Vertical motion departures were of the order of $10^{1}$ over KwaZulu-Natal and of the order of 1 at $60^{\circ} \mathrm{E}, 15^{\circ} \mathrm{S}$. The meridional overturning was reinforced by the wave train. It is concluded that the circulation contributed to the occurrence of the drought, not the thermodynamics. 
TABLE 1

Evaporative losses per day over KwaZulu/Natal during the 1992/93 dry summer

\begin{tabular}{|c|c|c|c|c|c|c|c|}
\hline Station & Period & $\begin{array}{c}\text { Mean } \\
\text { temp. }\left({ }^{\circ} \mathrm{C}\right)\end{array}$ & $\begin{array}{c}\text { RH } \\
(\%)\end{array}$ & $\mathrm{e}_{\mathrm{s}}(\mathrm{mb})$ * & $e_{a}(m b)$ & $\begin{array}{l}\text { Mean } \\
\text { wind } \\
\text { speed } \\
\left(\mathrm{m} \cdot \mathrm{s}^{-1}\right)\end{array}$ & $\begin{array}{l}\text { Evap./d } \\
(\mathrm{mm})^{* \star}\end{array}$ \\
\hline \multirow[t]{3}{*}{ Escourt } & $1992 / 12$ & 22.53 & 50.0 & 27.247 & 13.62 & 2.83 & 6.3 \\
\hline & $1993 / 01$ & 21.51 & 53.8 & 25.635 & 13.79 & 3.14 & 5.6 \\
\hline & $1993 / 03$ & 20.34 & 61.0 & 23.959 & 14.61 & 2.75 & 4.3 \\
\hline \multirow[t]{3}{*}{ Cedara } & $1992 / 12$ & 20.38 & 61.0 & 24.107 & 14.71 & 3.12 & 4.4 \\
\hline & $1993 / 01$ & 20.05 & 59.8 & 23.518 & 14.06 & 3.33 & 4.5 \\
\hline & $1993 / 03$ & 19.67 & 62.8 & 22.942 & 14.41 & 3.92 & 4.3 \\
\hline \multirow[t]{3}{*}{ Durban } & $1992 / 12$ & 23.94 & 61.1 & 29.652 & 18.12 & 4.17 & 5.9 \\
\hline & $1993 / 01$ & 24.22 & 56.1 & 30.191 & 16.94 & 3.14 & 6.3 \\
\hline & $1993 / 03$ & 24.57 & 58.2 & 30.923 & 18.00 & 2.75 & 5.9 \\
\hline
\end{tabular}

\section{Regional climatic patterns}

Regional climatic patterns contributing to dry conditions in KwaZulu-Natal in 1992/93 can be summarised as:

- a subtropical upper trough anomaly over eastern Africa;

- $>2 \mathrm{~m} \cdot \mathrm{s}^{-1}$ stronger westerly winds to the south;

- weak marine winds and cool sea temperatures to the south-west and east;

- a more intense anticyclonic gyre in the south-west Indian Ocean;

- an upper-level anticyclonic vorticity anomaly across the midlatitudes (Dube and Jury, 2002);

- surface divergence and upper convergence of the order of $2 \times 10^{6} \mathrm{~s}^{-1}$ over KwaZulu-Natal (Dube and Jury, 2002);

- a non-convective band that extended north-west-south-east into the mid-latitudes;

- an association with drought off equatorial east Africa;

- upper velocity potential dipole;

- wave trains and teleconnections with other centres of action in the region.

These patterns limit the development of cut-off low pressure systems, ridging anticyclones and tropical-temperate trough formation which are major rainfall-producing weather systems over KwaZulu-Natal.

\section{Synthesis and conclusions}

The analysis presented here indicates that pressures decreased south of South Africa causing low-level south-westerly flow. Anticyclonic vorticity and subsidence via upper-level convergence during the 1992/93 drought period suppressed convection in a manner similar to other dry years identified in earlier studies (Jury and Lyons, 1994).

Figure 5 is a flow chart of meteorological influences producing a below-normal rainfall scenario over KwaZulu-Natal. During the
1992/93 summer ascend over the Zambezi was offset by sinking over the Indian Ocean. The analyses point to the north-eastward relocation of the locus of major convective activity. Continental convection was reduced by a reversed meridional flux of energy over Southern Africa. The meridional temperature gradient was increased as suggested by Harrison (1986) and Preston-Whyte and Tyson (1988) and westerly mid-latitude storm tracks moved northward. Advection of anticyclonic vorticity weakened continental disturbances. Because of the eastward movement of the region of major convective activity, cloud bands formed preferentially over the Zambezi Valley and southern Madagascar while South Africa lost its major contributor to annual rainfall.

Drier conditions set in over south-eastern South Africa as the thermal low weakened and pressure increased over land. A negative geopotential height anomaly occurred near Gough Island in agreement with Tyson's (1986) dry scenario that includes the intrusion of subtropical upper westerly flow (Jury and Lyons, 1994; Parker and Jury, 1997).

Jury's (1992) analysis of SST in the central Indian Ocean indicates above-normal conditions coupled with low-level westerly wind anomalies east of Africa. Analysis of the 1992/93 summer seasons indicates a cool anomaly of the order of $\sim 0.3$ below normal over the central Indian Ocean, hence contradicting the normal El Niño-type drought scenario. Local surface air temperatures were about $2^{\circ} \mathrm{C}$ above normal during the 1992/93 season. SSTs were warm to the SE of Africa and this has been shown to be a characteristic feature of a higher rainfall over the region. Mason et al. (1994) have shown that the pattern of baroclinic westerly waves over the country may adjust to surrounding SST patterns.

The OLR and precipitable water analysis indicate that local convection was suppressed as a result of sinking motions and increased anticyclonic vorticity in the wave train. The OLR analysis shows that local dipole formed with positive anomalies, indicating sinking motions over South Africa in contrast with negative anomalies and rising motions over the Mozambique Channel $\left(40^{\circ} \mathrm{E}\right)$ during the drought period. 
The causes of the 1992/93 drought over KwaZulu-Natal can be summarised as follows:

- The upper circulation was dominated by a stationary wave in the westerlies over the subtropics.

- Local winds had a major influence in the production and persistence of the drought over KwaZulu-Natal.

- A significant 'memory' was carried to the DJF from the SON period. The widening of the confluent westerly wind anomaly and Indian Ocean SST during the DJF season, relative to SON, provide the most obvious evidence of this.

- The QBO and ENSO phase did not impose significant influences on rainfall over South Africa. The prominent SST signal is that of the immediate oceans, particularly the Indian Ocean.

- The cool SSTs to the east of Madagascar between 15 and $20^{\circ} \mathrm{S}$ induced a westward-directed zonal cell at these latitudes which combined with an N-S overturning cell between South Africa and the Zambezi.

- The deficiency of moist inflows southward from the Zambezi was one of the limiting factors to rainfall production.

- The kinematic properties of the circulation contributed more to the occurrence of the drought than thermodynamic properties.

- The north-south Hadley overturning between South Africa and the Zambezi which developed explains the occurrence of drought during this period.

Evidence presented in this paper suggests that the 1992/93 drought was characterised by a kinematic wave train not bearing any prominent ENSO signal. It is believed that the results of this study highlight some of the information required for long-range forecasting in addition to ENSO. Attempts should be made to understand decadal to intra-seasonal rainfall variability so that strategies can be implemented timely to minimise economic side-effects and take greater advantage of improved technology.

\section{Acknowledgements}

Much of the data were processed from the NCEP/NOAA website. V Botha, L Meyer and A Kozakiewicz are thanked for the annotation of graphs. Funding from the NRF provided the computer facilities.

\section{References}

BARCLAY JJ (1992) Wet and Dry Troughs Over Southern Africa During Early Summer. M.Sc. Thesis, Univ. of Cape Town.

CAMP KTG (1997) The Bioresource Groups of KwaZulu-Natal. Cedara Report No N/A/97/6. KwaZulu-Natal Department of Agriculture. Pietermaritzburg, South Africa.

CAMP KGT, MANSON AD, SMITH JMB, GUY RM and MILBORROW DJ (1995) The Bioresource Units of KwaZulu-Natal. Cedara Report No N/A/95/32. KwaZulu-Natal Department of Agriculture Pietermaritzburg, South Africa.

CRIMP SJ (1997) Modelling sea-surface temperature anomaly effects on South African rainfall using a mesoscale model. 5th Int. Conf. on South. Hemisphere Meteorol. Oceanogr., Pretoria, South Africa, 7-11 April. 122-123.

D'ABRETON PC and TYSON PD (1996) Three-dimensional kinematic trajectory modelling of water vapour transport over Southern Africa. Water SA 22(4) 297-306.

DUBE LT and JURY MR (2000) The nature of climate variability and impacts of drought over KwaZulu/Natal, South Africa. S. Afr. Geograp. J. 82 (2) 44-53.

DUBE LT and JURY MR (2002) Meteorological structure of the 1992/93 drought over eastern South Africa from ECMWF and satellite OLR analyses. S. Afr.Geograp. J. 84 (2) 170-181.
FARMER'S WEEKLY (1993) Planning for drought as a natural phenomenon - two survival strategies. 19 March 1993. 46-47.

FINANCIAL MAIL (1993a) GDP - Windfalls and rainfall. Financ. Mail. 129 (8) 35.

FINANCIAL MAIL (1993b) Summer crop: Dancing in the rain. Financ. Mail 130 (9) 92.

FINANCIAL MAIL (1993c) Agriculture: Badly managed farms. Financ. Mail 130 (1) 68-69.

HALTINER GJ and WILLIAMS RT (1980) Numerical Prediction and Dynamic Meteorology. John Wiley \& Sons. New York. 477 pp.

HARRISON MSJ (1986) A Synoptic Climatology of South African rainfall variations, Ph.D. Thesis, Univ. of Witwatersrand. $341 \mathrm{pp}$.

HASTENRATH S (1995) Recent advances in tropical prediction. Am. Meteorol. Soc. J. Clim. 8 (6) 1519-1532.

HUNT BG (1991) The simulation and prediction of drought. In: HendersonSellers A and Pitman AJ (eds). Vegetatio. 91, Kluwer Academic Publishers. Belgium. 89-103.

JURY MR (1992) A climatic dipole governing the interannual variability of convection over the SW Indian Ocean and SE Africa region. Trends in Geophys. Res. 1 165-172.

JURY MR (1996) Long-range Climate Forecasting and User Needs in Southern Africa. Draft report on the Workshop in reducing climaterelated vulnerability in Southern Africa held in Zimbabwe from 1-4 October 1996. 16-23.

JURY MR (1997) Long-range forecasting of South African summer rainfall using ENSO teleconnections. 5th Int. Conf. on South. Hemisphere Meteorol. and Oceanogr., 7-11 April, Pretoria, South Africa. 103-104.

JURY MR (1998) Statistical analysis and prediction of KwaZulu/Natal climate. Theor. and Appl. Climatol. 60 1-10.

JURY MR and LEVEY K (1993) The climatology and characteristics of drought in the Eastern Cape of South Africa. Int. J. Climatol. 13 629641.

JURY MR and LYONS W (1994) Contrasting synoptic weather events over Southern Africa in the dry summer of 1983. S. Afr. Geogr. J. 76 (1) $6-10$

JURY MR, McQUEEN C and LEVEY KM (1994) SOI and QBO signals in the African region. Theor. and Appl. Climatol. 50 103-115.

JURY MR, VALENTINE HR and LUTJEHARMS JRE (1993) Influence of the Agulhas Current on summer rainfall along the south-east coast of South Africa. J. Appl. Meteorol. 32 1282-1287.

LANDBOUWEEKBLAD (1993) Finansies en ekonomie - 'n Tweede droogte: Verdere ramphulp onontbeerlik. Landbouweekblad, 5 February.

LANDMAN WA (1994) Forecasts of South African summer rainfall using canonical correlation analysis. Experimental Long-Lead Forecast Bull. 3 (3) 28.

LANDMAN WA, KLOPPER E and BARTMAN AG (1997) Rainfall predictions for South Africa's neighbouring countries by means of CCA. 5th Int. Conf. on South. Hemisphere Meteorol. Oceanogr., Pretoria, South Africa, 7-11 April. 83-84.

LINDESAY JA (1988) The Southern Oscillation and Atmospheric Circulation Changes over Southern Africa. Unpublished $\mathrm{PhD}$ thesis, Univ. of the Witwatersrand, South Africa. 284 pp.

MASON SJ (1992) Sea Surface Temperatures and South African Rainfall Variability. Ph.D. Thesis, Univ. of the Witwatersrand, Johannesburg.

MASON SJ, JOUBERT AM, COSJIN C and CRIMP SJ (1996) Review of seasonal forecasting techniques and their applicability to Southern Africa. Water SA 22 (3) 203-209.

MASON SJ, LINDESAY JA and TYSON PD (1994) Simulating drought in Southern Africa using sea surface temperature variations. Water $S A$ 20 (1) $14-22$.

McILVEEN JFR (1986) Basic Meteorology. Van Nostrand Reinhold, Wokingham. $457 \mathrm{pp}$.

MONTECINOS A, ACEITUNOP and DIAZA (1997) Seasonal diagnostic and forecast of rainfall in subtropical South America based on Pacific SST. 5th Int. Conf. on South. Hemisphere Meteorol. Oceanogr., Pretoria, South Africa, 7-11 April. 97-98.

MULENGA HM (1998) Southern African Climatic Anomalies, Summer Rainfall and the Angola Low. Ph.D. Thesis, Univ. of Cape Town. 
MULLAN AB, FOLLAND CK, BASNETT TA and RENSHAW AC (1997) Simulation of multi-decadal climate variability in the South Pacific: 1871-1994. 5th Int. Conf. on South. Hemisphere Meteorol. Oceanogr., Pretoria, South Africa, 7-11 April. 35-36.

PARKER B A and JURY M R (1999) Synoptic environment of composite tropical cyclones in the southwest Indian Ocean. S. Afr. J. Marine Sci. 21 99-116.

PATHACK BMR, JURY MR, SHILLINGTON FA and COURTNEY S (1993) South African summer rainfall variability and its association with the marine environment. Water Research Commission Report No. 278/1/94, Pretoria, South Africa.

PRESTON-WHYTE RA and TYSON PD (1988) The Atmosphere and Weather of Southern Africa. Oxford University Press, Cape Town, 178-276.

RAUTENBACH CJ deW (1997) Seasonal variability in observed and GISST simulated rainfall over Southern Africa. 5th Int. Conf. on South. Hemisphere Meteorol. Oceanogr., Pretoria, South Africa, 7-11 April. 105-106.

ROCHA A and SIMMONDS I (1997a) Interannual variability of southeastern African summer rainfall - Part I: Relationships with air-sea interaction processes. Int. J. Climatol. 17 235-265.

ROCHA A and SIMMONDS I (1997b) Interannual variability of southeastern African summer rainfall - Part II: Modelling the impact of seasurface temperatures on rainfall and circulation. Int. J. Climatol. 17 267-290.
RONCHAIL J (1997) Interdecadal variability of rainfall in Bolivia and sea-surface temperatures. 5th Int. Conf. on South. Hemisphere Meteorol. Oceanogr., Pretoria, South Africa, 7-11 April. 99-100.

SCHULZ EF (1976) Problems in Applied Hydrology. Water Resources Publications, Fort Collins, Colorado, USA, 197-210.

SOUTH AFRICAN WEATHER BUREAU (1992 South African Weather Bureau Newsletter No. 514, Department of Environmental Affairs, South Africa.

THE SOUTH AFRICAN SUGAR ASSOCIATION (1993a) Drought cuts growers revenue by R790 million. The South African Sugar Association, July 1993. 182-186.

THE SOUTH AFRICAN SUGAR ASSOCIATION (1993b) Bitter harvest of a two-year drought. South African Sugar Association, August 1993. 222.

THE SOUTH AFRICAN SUGAR ASSOCIATION (1993c) Rural communities menaced by drought: "Operation Amanzi" offers a water lifeline. South African Sugar Association, September 1993, 262.

THIAO W and BARNSTON AG (1997) Long-lead predictability of summer rainfall in Southern Africa. 5th Int. Conf. on South. Hemisphere Meteorol. Oceanogr., Pretoria, South Africa, 7-11 April. 156157.

TYSON PD (1986) Climate Change and Variability in Southern Africa. Oxford Univ. Press, Cape Town. 220 pp.

WALKER ND (1989) Sea-Surface Temperature-Rainfall Relationships and Associated Ocean-atmosphere Coupling Mechanisms in the Southern African Region. Unpublished PhD Thesis, Univ. of Cape Town. $173 \mathrm{pp}$. 